\title{
Humpback whale, Megaptera novaeangliae, song during the breeding season in the Gulf of Tribugá, colombian Pacific
}

Christina E. Perazio', ", Maria E. Zapetis', Dana Roberson!, Natalia Boterol, "I, Stan Kuczaj"l"

\section{ABSTRACT}

A key feature of humpback whale behavior, documented primarily on the breeding grounds, is the repertoire of the males' song. Song is made up of single units combined together into phrases, which are repeated to make up themes. A song consists of several themes sung in succession. This study qualitatively investigates the presence and structure of song recorded in the Gulf of Tribugá in the Colombian Pacific. Data were collected between June and September 2013, from which approximately 4 hours and 30 minutes of song were analyzed from five individual whales. Three distinct themes, always sung in the same order (theme 1-theme 2theme 3) were identified. Theme 1 was the most predominant theme overall, and was present in each song session that was analyzed. The structure of each theme is described with accompanying spectrograms, and specific acoustic parameters further illustrate theme progression and characterize differences between whales. This study serves as the first published descriptive analysis of the song of stock $\mathrm{G}$ in this area, and suggestions are made for future directions of investigation. Research on humpback song is used as a part of the overall efforts of Macuáticos Colombia Foundation to educate the communities of the Gulf of Tribugá about the importance of conservation, and to advocate for stricter guidelines for safe whale-watching practices.

\section{RÉSUMÉ}

Les baleines à bosse ont été observées dans le monde entier et elles migrent chaque année entre leurs zones de nourrissage dans les latitudes élevées et les aires de reproduction aux latitudes basses. Le chant des baleines à bosse est I'un des comportements lié à l'accouplement qui a été documenté sur les aires de reproduction. Ce chant est composé d'unités simples combinées dans des phrases et qui sont répétées pour composer des thèmes. Les chants sont composés de plusieurs thèmes et sont principalement émis par les mâles. L'étude actuelle a porté sur la présence et la structure du chant des baleines à bosse du G-stock enregistré dans le golfe de Tribugá dans le Pacifique colombien.
Correspondence:

Christina E. Perazio

Psychology Department, University of Southern Mississippi, Hattiesburg, MS, 39406, United States.

Email: perazio.ce@gmail.com

Les données ont été recueillies entre juin et septembre 2013 à l'aide d'un hydrophone SQ26-08 au cours d'excursions en bateau qui se sont déroulées 3 fois par semaine. La structure du chant a été codée en utilisant Raven Pro 1.4. Environ 4 heures et 30 minutes de chant ont été analysées et les chercheurs ont identifié trois thèmes distincts qui ont toujours été entendus dans le même ordre. Le thème 1 dominait dans tous les enregistrements et était composé de répétitions de légères variations de l'expression 'ABABABAA'. Le thème 2 était composé de répétitions des unités ' $F$ ' et 'Bl', avec des variations de la phrase de multiples unités répétées dans une rangée. Le thème 3 était composé de phrases répétées d'une unité longue 'upsweep' tonale 'LU', suivie par une unité courte 'upsweep' tonale 'SU', parfois avec une unité 'downsweep' dans le motif. L'unité 'S' a été entendue pendant les transitions du thème 3 au thème 1 . Le thème 1 a été entendu beaucoup plus fréquemment que les autres thèmes et le thème 3 était le moins fréquemment enregistré. La structure changeante de chaque thème a été décrite avec des spectrogrammes d'accompagnement et les paramètres acoustiques ont été utilisés pour différencier les unités. Cette étude est la première analyse descriptive du chant du stock $\mathrm{G}$ dans ce domaine et des suggestions sont proposées pour les orientations futures de l'étude. Les enregistrements sonores ont été utilisés pour soutenir les efforts déployés par la Fondation Macuáticos Colombie pour sensibiliser éduquer les communautés du golfe de Tribugá sur l'importance de la conservation et pour renforcer les directives portant sur les pratiques sécurisées d'observation des baleines et de la pêche.

\section{INTRODUCTION}

Humpback whales are a cosmopolitan species that annually migrate between high-latitude feeding areas and low-latitude breeding areas. Behaviors exhibited by humpback whales in breeding areas help researchers better understand group social dynamics and conspecific communication (Winn and Winn 1978, Darling 2001). One such behavior is the singing of reproductive male humpback whales (Winn and Winn 1978). Humpback whale song

\footnotetext{
I Psychology Department, University of Southern Mississippi, Hattiesburg, MS, 39406, United States

॥ Fundación Macuáticos Colombia, Medellín, Antioquia, Colombia

Citation Perazio, C. E., Zapetis, M. E., Roberson, D., Botero, N. and Kuczaj II, S. 2017. Humpback whale, Megaptera novaeangliae, song during the breeding season in the Gulf of Tribugá, Colombian Pacific. Madagascar Conservation \& Development. 13, 1:83-90 http://dx.doi.org.10.4314/mcd.whales.1
} 


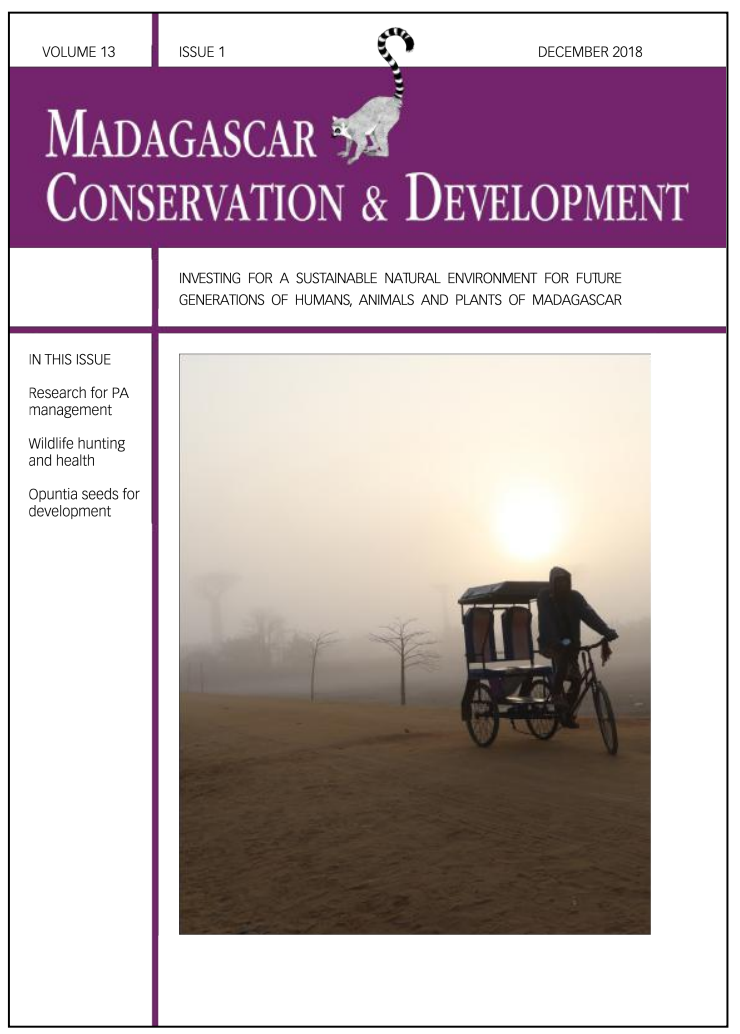

Madagascar Conservation \& Development is the journal of Indian Ocean e-Ink. It is produced under the responsibility of this institution. The views expressed in contributions to MCD are solely those of the authors and not those of the journal editors or the publisher.

All the Issues and articles are freely available at http://www.journalmcd.com

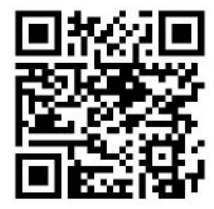

Contact Journal MCD

info@journalmcd.net for general inquiries regarding MCD funding@journalmcd.net to support the journal

Madagascar Conservation \& Development Institute and Museum of Anthropology

University of Zurich

Winterthurerstrasse 190

$\mathrm{CH}-8057$ Zurich

Switzerland

Indian Ocean e-Ink

Promoting African Publishing and Education

www.ioeink.com

Missouri Botanical Garden (MBG)

Madagascar Research and Conservation Program

Missouri Botanical Garden

BP 3391

Antananarivo, 101, Madagascar 
has been documented in many breeding areas (Payne et al. 1983, Payne and Payne 1985, Cerchio et al. 2001, Darling and SousaLima 2005, Eriksen et al. 2005, Murray et al. 2012, Oviedo et al. 2008). Additionally, song has been recorded during migration (Norris et al. 1999, Noad et al. 2000) and on a few feeding grounds (Clark and Clapham 2004, Stimpert et al. 2012, Garland et al. 2013).

Humpback whale song was initially described by Payne and McVay (1971) as being hierarchical in structure, in that a song will consist of a series of sound clusters that are termed units, phrases, and themes that repeat to form the succeeding cluster. A unit is defined as the shortest continuous sound to the human ear (Payne and McVay 1971). Cerchio et al. (2001) found that units can have fundamental frequencies ranging from $30 \mathrm{~Hz}$ to over 10,000 $\mathrm{Hz}$. A phrase is an organized pattern of 2-20 or more units (Cerchio et al. 2001), which repeats with slight variation to form a theme (Payne and McVay 1971). A song is a series of discrete ordered themes, which can range in length from 8 to 16 minutes. However, some recordings demonstrate that songs can last for over 35 minutes (Payne and Payne 1985). A series of several songs repeated without pause is termed a song session. Song sessions can endure for several hours (Payne and McVay 1971).

Individual whales have been recorded altering their song throughout the breeding season (Payne and McVay 1971) and across different seasons (Guinee et al. 1983) by adding new units and reordering previously sung units (Winn and Winn 1978). This behavior is not restricted to individual whales, but rather these changes are often represented within the whole population (Winn \& Winn 1978, Guinee et al. 1983, Payne et al. 1983, Payne and Payne 1985). Many similarities have even been noted between distinct populations (Winn et al. 1981, Cerchio et al. 2001, Darling and Sousa-Lima 2005, Garland et al. 2013). Due to the nature of migration, these distinct populations are able to transmit song across large distances (Noad et al. 2000, Clark and Clapham 2004, Darling and Sousa-Lima 2005). Cultural transmission is thought to be one of the possible explanations for these large-scale changes and similarities within and between populations (Guinee et al. 1983, Payne et al. 1983, Garland et al. 2011).

With such a large-scale transmission, the song structure from each distinct population needs to be documented in order to characterize longitudinal and geographic progression of song. The authors identified the Gulf of Tribugá as a breeding ground where no recordings of humpback whale song had previously been reported. It was the aim of this study to describe the structure of the southeastern Pacific (stock G) song from the Gulf of Tribugá in the colombian Pacific.

\section{METHODOLOGY}

STUDY SITE. The current study was conducted in coastal waters of the Gulf of Tribugá, located in the northern Colombian Pacific within the state of Chocó. The gulf limits are El Valle, municipality of Bahía Solano (W077 $25^{\prime}, \mathrm{N} 06^{\circ} 06^{\prime}$ ) to the north, and Cape Corrientes, municipality of Nuquí (W077 $16^{\prime}, \mathrm{N}^{\circ} 5^{\circ} 43^{\prime}$ ) to the south (Díaz 2002). Boat trips originated from the small fishing village of Coquí $\left(\mathrm{W}_{077^{\circ}} 21^{\prime}, \mathrm{N}^{\circ} 5^{\circ} 36^{\prime}\right)$, located in the southwestern section of Tribugá's Gulf. The Gulf of Tribugá is located within the Inter-tropical Convergence Zone influence. As a consequence, weather is characterized by low winds and high pluviosity (Eslava 1993). Considering the interaction of superficial marine currents and freshwater from the continent, coastal waters tend to be turbid. Sea surface temperature is relatively warm $\left(22-28^{\circ} \mathrm{C}\right)$ and of medium-low salinities (Cantera 1993, Díaz 1998). Tides are characterized by a macro-tidal regime of up to 5 meters (Jaramillo and Bayona 2000, Díaz 2002). The Gulf of Tribugá is characterized by a considerably narrow and inclined continental shelf, and as such, the $300 \mathrm{~m}$ isobath is located only a few kilometers from the coast (Galvis and Mojica 1993).

DATA COLLECTION. Acoustic data were collected between 7 June and 13 September 2013 within coastal waters of the Gulf of Tribugá in the Colombian Pacific. Within this time period, recordings were made on 28 days, totaling 49 recording sessions. Date, GPS coordinates, photographs (if applicable), and environmental measurements (e.g., weather, salinity, and sea state) were collected in situ (Table S1.1). Boat surveys using an eight-meter fiberglass boat with an outboard motor alternated north and south from Coquí to limit the chance of re-sightings (see Payne et al. 1983). The research team conducted these surveys three times per week for approximately 8 hours per day, weather and fuel permitting. These trips were a part of data collection efforts by Macuáticos Colombia Foundation that included photo-identification and behavioral studies in addition to acoustic data collection. A single SQ26-08 hydrophone with a 0.02 to $50 \mathrm{kHz}$ frequency range and $100 \mathrm{~m}$ maximum operating depth was connected to a 24-bit Zoom H1 digital recorder with $96 \mathrm{kHz}$ sampling rate, $40 \mathrm{kHz}$ recording capacity, and automatic gain settings turned off for more accurate reporting of measurements (Au and Hastings 2008). The hydrophone was deployed to the full extent of the $10 \mathrm{~m}$ cord whenever singers were detected, either visually or audibly. Recordings began only when song was clear and consisted of no more than two whales, and if possible, continued for the duration of the song. Given the reduced visibility encountered in the Gulf of Tribugá, the possibility of identifying individual whales underwater was limited. However, the authors registered 144 individual whales via fluke photographs in 2010 and 2013, and there was only one known re-sighting of those individuals. Moreover, the current estimation of 4000 individual whales in stock G (Clapham and Mead 1999) produces a very small likelihood of recording the same whale twice. Therefore, authors assumed that recordings made in a different area on a different day contained different individuals (see also Guinee et al. 1983, Payne et al. 1983). This assumption is adequate for the descriptive nature of this study.

DATA ANALYSIS. All recordings were screened for quality to determine which songs could be analyzed. Songs met the inclusion criteria if they contained one predominant singer and if they had sufficient signal-to-noise ratios (SNR) greater than $10 \mathrm{~dB}$, and on average $24.95 \mathrm{~dB} \pm 10.31 \mathrm{~dB}$, such that all units were easily visible above ambient noise. Only recordings with these SNR values were transcribed, ensuring that all frequency parameters of each unit were visible and no units were missed in the analysis (Cholewiak et al. 2013). Not all recordings met the inclusion criteria due to the frequent and interspersed interruption of ambient noise. Ambient noise was defined as containing some environmental (e.g., wind, waves) or anthropogenic (e.g., water craft) features, as well as song from other humpback whales in the distance. The song sessions of five different whales met the inclusion criteria and were included in the final analysis (Table 1). Raven Pro 1.4 bioacoustics software (Bioacoustics Research Program, Cornell Lab of Ornithology) was used to create time by frequency spectrograms (4096 FFT, Hann window, 50\% overlap, 
window size 4045 for precise frequency measurements, hop size $31.5 \mathrm{~ms}$ ) of high quality recordings to qualitatively describe the song structure (Figure 1). Spectrograms were transcribed for the individual units, phrases, and themes that constituted each song. Three independent observers [CEP, MEZ, DR] transcribed a subset of each theme from spectrograms, including both unit and phrase structure, both aurally and visually, to develop a reliable scheme for transcription. Authors [CEP, MEZ, DR] analyzed one entire recording together, to become familiar with the song structure (J. Darling, pers. comm. 2014). Subsequently, each observer analyzed a second recording independently for unit, phrase, and theme structure. Authors agreed upon this structure $90 \%$ of the time. Predominant discrepancies in transcription related to the exact start and end times for each theme. However, all discrepancies were addressed and collaboratively transcribed by the authors as a group. Acoustic parameters were measured for individual units using Raven Pro sound analysis software, and included duration (seconds), highest, lowest, and fundamental frequency (hertz). For reliability, each author analyzed a subset $(25 \%)$ of the total data. High reliability on acoustic parameter transcription (85\% agreement) was required before authors began transcribing independently. For analysis, acoustic parameters were measured for the first, middle, and last minute of each complete song within a recording. To ensure consistency and reliability in the transcription of phrases, rules suggested by Cholewiak et al. (2013) were applied. Specifically, subphrases, defined as distinct repetitions of units in a repeating pattern that together make up a phrase (Payne et al. 1983, Cholewiak et al. 2013) were maintained within phrases, and phrases were labeled to separate complete patterns of units (Cholewiak et al. 2013). For descriptive analyses, phrases were unambiguously associated with a particular theme type, as determined through inter-observer agreement between three of the authors [CEP, MEZ, DR]. Transitional phrases, which occurred when the structures of the previous and consecutive themes combined (Payne and Payne 1985), were analyzed separately from the three main themes.

\section{RESULTS}

Approximately 285 minutes of song were recorded during the 2013 season, of which 219 minutes (77\% of the data) were analyzed. Three distinct themes (Figure 1) were found in each song, and these were composed of 11 units (Figure 2, Table S1 (modeled after the approach of Au et al. 2006)). In total, approximately 158.5 minutes of theme 1, 42.5 minutes of theme 2 , and 18 minutes of theme 3 were recorded. The longest song session consisted of seven complete songs. Additionally, these themes were consistently heard in the same order throughout all five recordings. Individuals did not deviate from this theme order or skip themes. It cannot be determined if theme 1 was the first theme of each song, since recordings often began in the middle of a song.
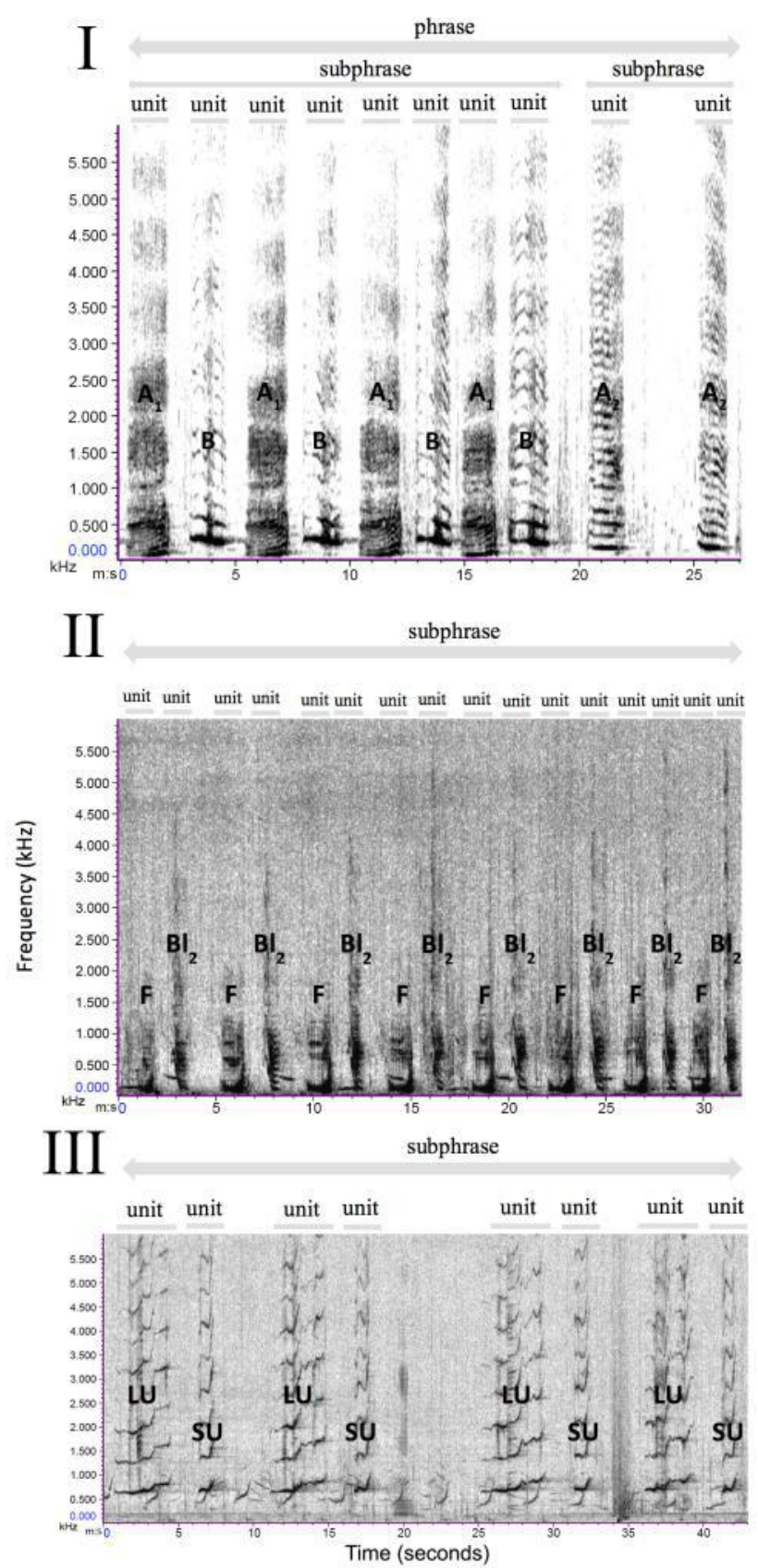

Figure 1. I. Spectrogram of theme 1 illustrating the phrase structure from whale 4. Subphrase $1 \mathrm{~A}$ includes four repetitions of two units (A1 and B), and subphrase $1 \mathrm{~B}$ is a single $A 2$ unit repeated twice. II. Spectrogram of theme 2 illustrating

subphrase $2 A$, the most common subphrase structure, from whale 4 . These two units ( $F$ and $B / 2$ ) are repeated eight times within this subphrase. III. Spectrogram of theme 3 illustrating subphrase $3 \mathrm{~A}$, the most common subphrase structure, from whale 3 . This rendition of the subphrase consists of 4 repetitions of two units (LU and SU). High frequencies extended beyond the cut off. However, all themes (I, II, and III) have the same cut off for the purposes for this figure. Spectrograms created in Raven 1.4 Hann window with an FFT of 4096 and an overlap of $50 \%$. Time (seconds) is along the $\mathrm{x}$-axis and frequency $(\mathrm{kHz})$ is along the $y$-axis.

Table 1. Quantitative summary of the analyzed recordings for the Colombia 2013 songs.

\begin{tabular}{|c|c|c|c|c|c|c|c|c|c|}
\hline Date (2013) & $2 \mathrm{VIII}$ & $9 \mathrm{VIII}$ & $9 \mathrm{VIII}$ & $12 \mathrm{VIII}$ & $12 \mathrm{VIII}$ & $9 I X$ & $9 I X$ & $13 \mathrm{IX}$ & Totals \\
\hline Whale \# & 1 & 2 & 2 & 3 & 3 & 4 & 4 & 5 & \\
\hline Duration of Recording & $00: 34: 41$ & 01:02:08 & $00: 40: 55$ & $00: 06: 57$ & 00:32:04 & $00: 12: 43$ & $00: 37: 07$ & $00: 58: 06$ & $04: 44: 41$ \\
\hline Total Number of Songs & 3 & 7 & & 2 & & NA & 2 & 4 & \\
\hline Total Number of Themes & 9 & 22 & & 2 & 8 & 1 & 7 & 13 & \\
\hline Theme Order & $1-2-3$ & $1-2-3$ & $1-2-3$ & $1-2-3$ & $1-2-3$ & 1 & $1-2-3$ & $1-2-3$ & \\
\hline Total Duration of Theme 1 & $00: 18: 32$ & $00: 32: 23$ & $00: 17: 38$ & $00: 05: 33$ & $00: 18: 31$ & $00: 12: 14$ & $00: 22: 37$ & $00: 30: 59$ & $02: 38: 27$ \\
\hline Total Duration of Theme 2 & $00: 05: 34$ & 00:08:01 & $00: 10: 05$ & $00: 00: 00$ & $00: 00: 57$ & 00:00:00 & $00: 06: 47$ & $00: 11: 15$ & $00: 42: 39$ \\
\hline Total Duration of Theme 3 & $00: 03: 28$ & 00:03:19 & $00: 02: 33$ & 00:00:08 & $00: 01: 24$ & 00:00:00 & $00: 02: 01$ & 00:05:06 & $00: 17: 59$ \\
\hline
\end{tabular}




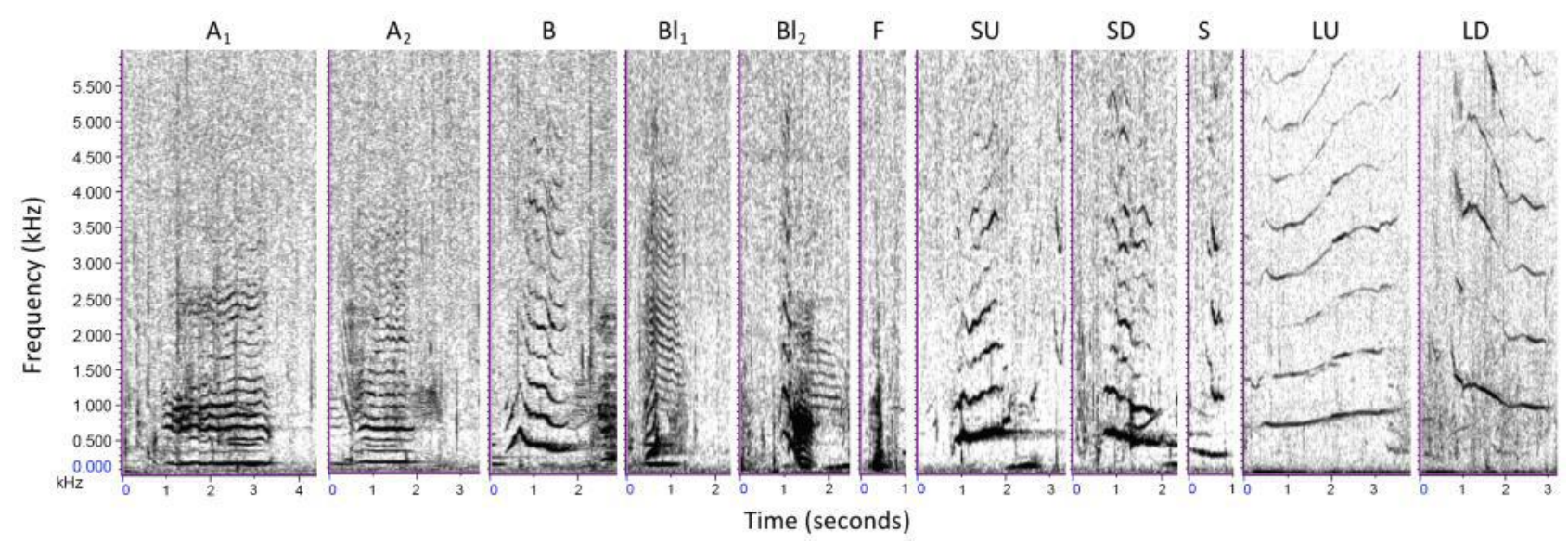

Figure 2. Spectrographic depictions of each unit type from the 2013-breeding season. Spectrograms created in Raven 1.4 Hann window with an FFT of 4096 and $50 \%$ overlap. All units have the same frequency cut off for the purposes for this figure.

THEME DESCRIPTION. Theme 1 was made up of three units

( $A 1, B$, and $A 2$ ) that formed slight variations of the phrase A1BA1BA1BA1B A2A2 (Figure 1.I). Within this phrase, there were two subphrases (Figure 3.I). Subphrase $1 A$ consisted of the unit $A 1$ and unit $B$. The pattern A1B was usually repeated on average 6.14 \pm 2.33 times in a phrase, but it was produced as few as 4 and as many as 17 times. There was no consistent pattern to the differing number of $\mathrm{A} 1 \mathrm{~B}$ repetitions within a recording or across the breeding season. These variations were consistent with the current understanding of subphrase structure (Cholewiak et al. 2013). Subphrase 1B consisted only of the unit A2, repeated a variable number of times (Figure 3.I). Unit A2 was labeled separately from unit A1 due to acoustic distinctions. Unit A1 had a greater frequency range and higher average frequency than $A 2$; however, A2 had a higher average fundamental frequency (Table S1). Subphrase 1B is considered a "similar motif" according to the description of song structure proposed by Winn and Winn (1978), as unit A2 was the only unit in the subphrase (Figure 3.I). This subphrase most commonly manifested as a double repetition (A2A2, mean \pm $\mathrm{SD}, 7 \pm 3.87)$ within a theme rendition. However, subphrase $1 \mathrm{~B}$ was occasionally expressed as a single $\mathrm{A} 2(2 \pm 1.73)$ or a triple repetition $(A 2 A 2 A 2,1 \pm 0)$. Although the subphrase $1 A$ was always followed by subphrase $1 \mathrm{~B}$ predictably, the five whales varied in their use of the second subphrase. All five whales used A2A2 in subphrase $1 \mathrm{~B}$. Whale 1 and whale 5 varied between $A 2$ and $A 2 A 2$ in subphrase $1 B$, whale 2 used only $A 2 A 2$ in subphrase $1 B$, whale 3 used either $A 2 A 2$ or $A 2 A 2 A 2$ in subphrase $1 B$, and whale 4 varied between $A 2, A 2 A 2$, and $A 2 A 2 A 2$ in subphrase $1 B$.

Both frequency and duration parameters further differentiated the individual units identified within theme 1. On average, unit B had a greater average high $(4319.1 \mathrm{~Hz})$ and a greater average low frequency $(207.5 \mathrm{~Hz})$ compared to both $\mathrm{A} 1(3479.9 \mathrm{~Hz}$, 117.4 Hz) and A2 (4103.0 Hz, 102.0 Hz). This was also evident in the aural classification of units (Table S1). Additionally, unit A2 did not reach the low frequencies that both $A 1$ and $B$ did. Unit $A 1$ had a greater average duration than either $\mathrm{A} 2$ or $\mathrm{B}$, but also the greatest range of duration (Table S1).

Theme 2 was comprised of phrases that included three units (B|1, Bl2, and F). Each phrase was broken into two subphrases, but was primarily composed of subphrase 2A (Figure 1.II, Figure 3.II). Subphrase $2 \mathrm{~A}$ consisted of a variable number of $\mathrm{F}$ and $\mathrm{Bl}$ (either $\mathrm{B} \mid 1$ or $\mathrm{B} \mid 2$ ) repetitions (Figure 3.II). The BI unit was characterized as either $\mathrm{B} 11$ or $\mathrm{B} / 2$ based on acoustic parameters and spectrogram appearance (Figure 3.II, Table S1). Clear harmonics were not present in the $\mathrm{Bl} 2$ unit. Unit $\mathrm{Bl} 2$ had a higher average fundamental frequency $(486.6 \mathrm{~Hz})$ and average high frequency $(2872.7 \mathrm{~Hz})$ than unit BI1 (Table S1). With the exception of the S unit (theme 3), unit Bl1 had the shortest average duration of all units in the dataset (0.5 s). These differences are consistent with literature that explains the gradual changing nature of phrases within a theme with respect to both frequency and duration parameters (Cholewiak et al. 2013). All whales utilized both $B \mid 1$ and $B \mid 2$ units in subphrase $2 \mathrm{~A}$ in at least one song within their song session. Variations consisted of an average of $4.58 \mathrm{~F}-\mathrm{B} / 2$ repetitions $(\mathrm{SD}=3.50$ ) alternating with an average of $4.9 \mathrm{~F}-\mathrm{B} / 1$ repetitions ( $S D=5.20)$. Subphrase $2 \mathrm{~B}$ consisted of a variable number of $\mathrm{F}$ units (Figure 3.II) and is also a "similar motif" (Winn and Winn 1978). Not all whales sang this subphrase, but in all instances within the dataset it followed subphrase $2 \mathrm{~A}$. Unit $\mathrm{F}$ had the lowest average fundamental frequency of all units in the dataset $(209.9 \mathrm{~Hz})$.

Whale 1 exhibited variations to the phrase structure of theme 2 that no other whale used, including repetitions of $F$ and $2 \mathrm{Bl} 2$ units (mean $\pm S D, 2 \pm 1.41$ ), repetitions of $F$ and $3 \mathrm{Bl} 2$ units (mean=1), a single phrase of $\mathrm{F}$ and $4 \mathrm{Bl} 2$ units, and a single phrase of $\mathrm{F}$ and $5 \mathrm{Bl} 2$ units. Whale 2 , whale 4 , and whale 5 produced an average of $2 \pm 0.71 \mathrm{~F}$ unit repetitions, while whale 3 was the only whale to repeat the $\mathrm{Bl} 1$ unit twice.

Theme 3 was characterized by phrases with five tonal units (LU, SU, LD, SD, S) and two subphrases (Figure 3.III). Each phrase was primarily composed of subphrase $3 \mathrm{~A}$, which consisted of a varying number of repetitions of a long, tonal upsweep (LU) unit followed by a short, tonal upsweep (SU) unit (Figure 1.III). Subphrase $3 \mathrm{~B}$ always consisted of fewer repetitions than $3 \mathrm{~A}$, and included alternating long and short downsweep units (LD and SD) and $\mathrm{S}$ units (Figure 3.III). The pattern of units within subphrase 3B changed across phrase repetitions, which is supported in the literature (Cholewiak et al. 2013). Subphrase 3A persisted throughout every rendition of theme 3 in all five whales. However, whale 1 and whale 5 were the only individuals to incorporate subphrase 3B (Figure 3.III). Long units, upsweep or downsweep, ranged in duration between 1.8-4.3 seconds, and short units ranged between 0.5-1.5 seconds (Table S1). LU units had a greater average and range of duration compared to LD units. On average, SD units (1.0 s) were slighter shorter than LD units (2.6 s), but were similar in average duration to SU units (1.2 s). All upsweep units were lower in measured frequency parameters in comparison to downsweep units (Table S1). The S unit had the shortest average duration of all units in the dataset $(0.3 \mathrm{~s})$ with the highest average frequency (15776.3 Hz). 


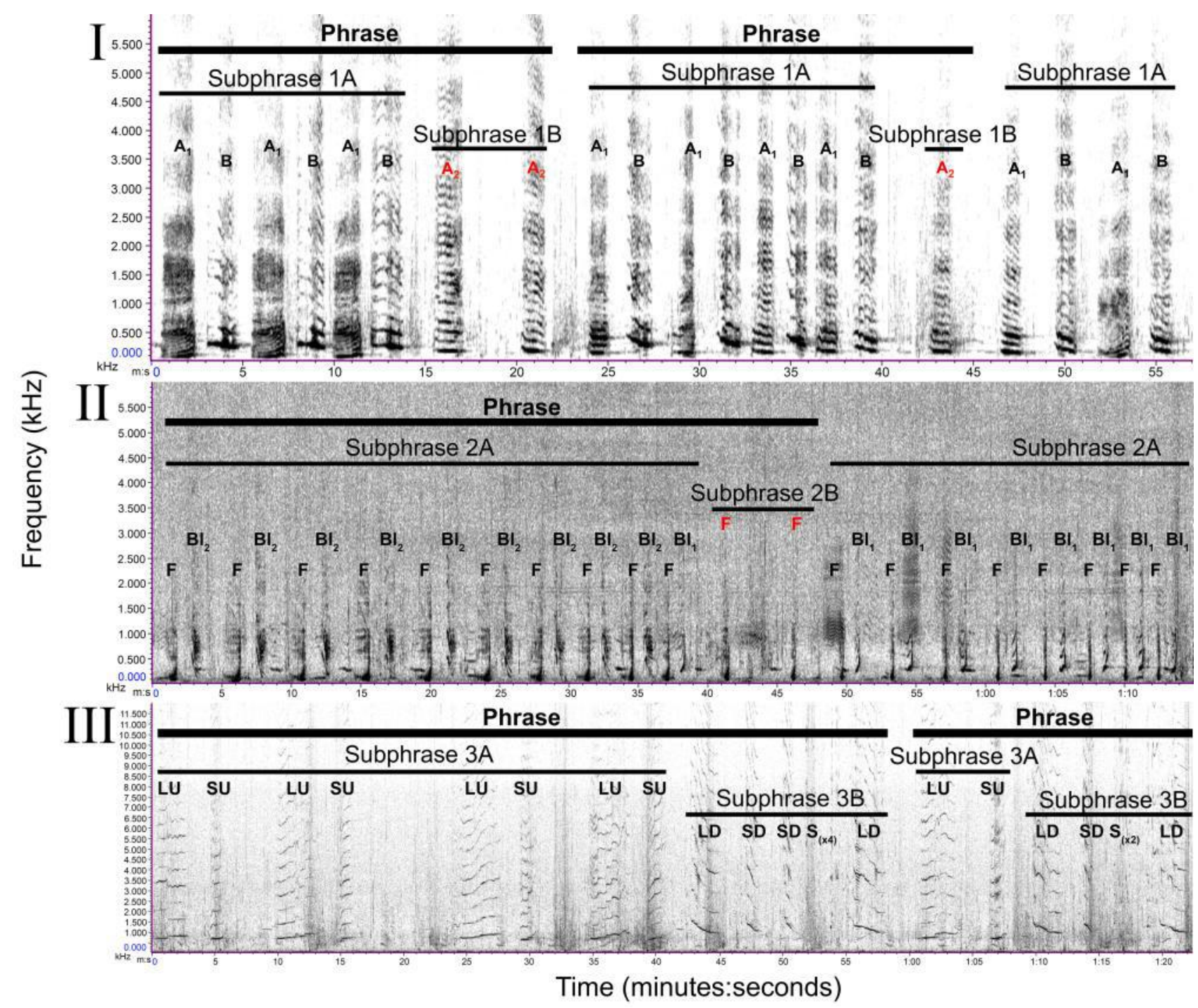

Figure 3.I. Spectrographic depiction of whale 4's variation on theme 1, illustrating the use of A2A2 vs. A2. This spectrogram shows 2 complete phrase renditions, and the beginning (of subphrase 1A) of a third phrase. II. Spectrographic example of theme 2 's phrase structure from whale 4 . Subphrase $2 \mathrm{~A}$ consists of 10 repetitions of units $\mathrm{F}$ and $\mathrm{Bl}$, nine of which use $\mathrm{B} \mid 2$ and one uses $\mathrm{B} \mid 1$. Subphrase $2 \mathrm{~B}$ consists of $2 \mathrm{~F}$ units repeated. Whale 4 is one of three whales that use subphrase $2 \mathrm{~B}$. The next rendition of subphrase $2 \mathrm{~A}$ marks the start of a new phrase, this time with 8 repetitions of $\mathrm{F}$ and Bl1. III. Spectrographic example of theme 3 's phrase structure from whale 1. This theme rendition begins with 4 repetitions of $L U$ and SU units (subphrase $3 A$ ). Subphrase 3B consists of LD, SD, and S units. The second subphrase 3A marks the start of the second phrase. Spectrograms created in Raven 1.4 Hann window with an FFT of 4096 and an overlap of $50 \%$. Time (minutes:seconds) is along the $x$-axis and frequency $(\mathrm{kHz})$ is along the $\mathrm{y}$-axis.

Two transitional phrases were identified in the dataset: phrase 1-2 (Figure 4.I) and phrase 3-1 (Figure 4.II). No consistent transition was found between themes 2 and 3 . These phrases were simple, and included a combination of units from two phrase types, one from each of the themes they separated. All five whales produced phrase 3-1, and phrase 1-2 was identified from all recordings with the exception of whale 1 . These transitional phrases were consistent throughout the song sessions of each whale.

DURATION ANALYSES. The duration of each theme per individual whale was analyzed due to its importance and discussion in early song studies (Payne et al. 1983). It is evident that the three main themes were not used equally (Figure 5). Across all recordings, the average duration of theme 1 (424 S) accounted for the greatest proportion of the song when compared to themes 2 (120 s) and 3 (53 s) (Figure SM1.2A). More specifically, the number of renditions (i.e., each time a specific theme was heard within a single whale's song session) was analyzed. Theme 1, 2, and 3 comprised $39 \%, 30 \%$, and $31 \%$ of total theme renditions, respectively (Figure SM1.2B). In summary, while theme 1 was longer in duration when compared to the two other themes, the use of each theme over the season was fairly similar.

The duration of each theme was also compared across individual whales. For each whale, theme 1 constituted the greatest average duration across song sessions, and theme 3 constituted the smallest average duration, with the exception of whale 3 (Figure 5). Whale 3 was the only individual to consistently spend more time singing theme 3 than theme 2 (Figure 5, Figure 6). When duration values were measured for each consecutive theme rendition within a whale's song session, theme 1 was consistently the longest theme, with the exception of whale 5 's first song (Figure 6). There was a trend for the durations of theme 1 for whales 2, 3, and 5 to evolve in a bell-shaped distribution over the course of the song session (Figure 6). This pattern was also true in theme 2 for whales 1 and 4 (Figure 6).

Song duration followed a reliable pattern in each recording. The shortest complete song recorded was 7 minutes and $21 \mathrm{sec}$ - 


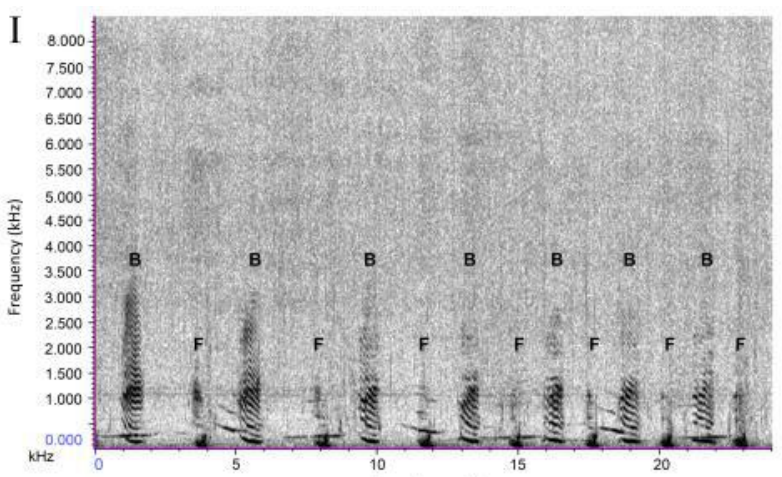

Time (seconds)

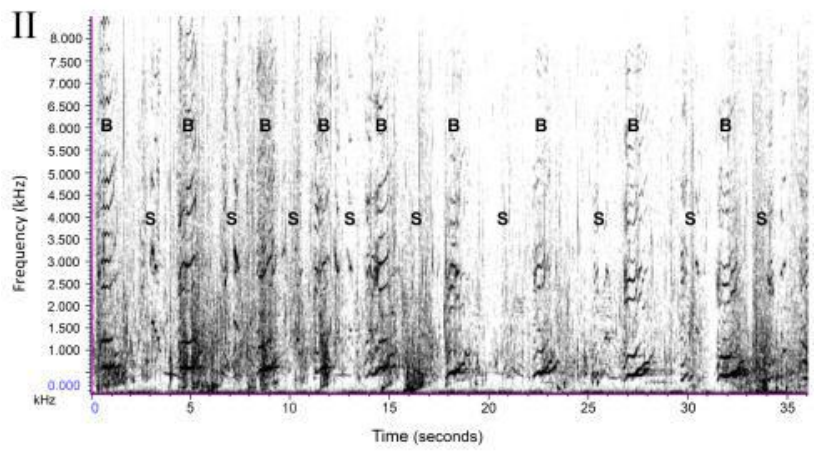

Figure 4. Spectrograms of transitional phrases. I. Phrase 1-2 (from whale 4) is the common transition between themes 1 and 2, and consists of alternating $B$ units (theme 1) and F units (theme 2). II. Phrase 3-1 (from whale 1) persists between themes 3 and 1 , and consists of alternating B units (theme 1) and $S$ units (theme 3). Spectrograms created in Raven 1.4 Hann window with an FFT of 4096 and an overlap of $50 \%$. Time (seconds) is along the $\mathrm{x}$-axis and frequency $(\mathrm{kHz})$ is along the $y$-axis.

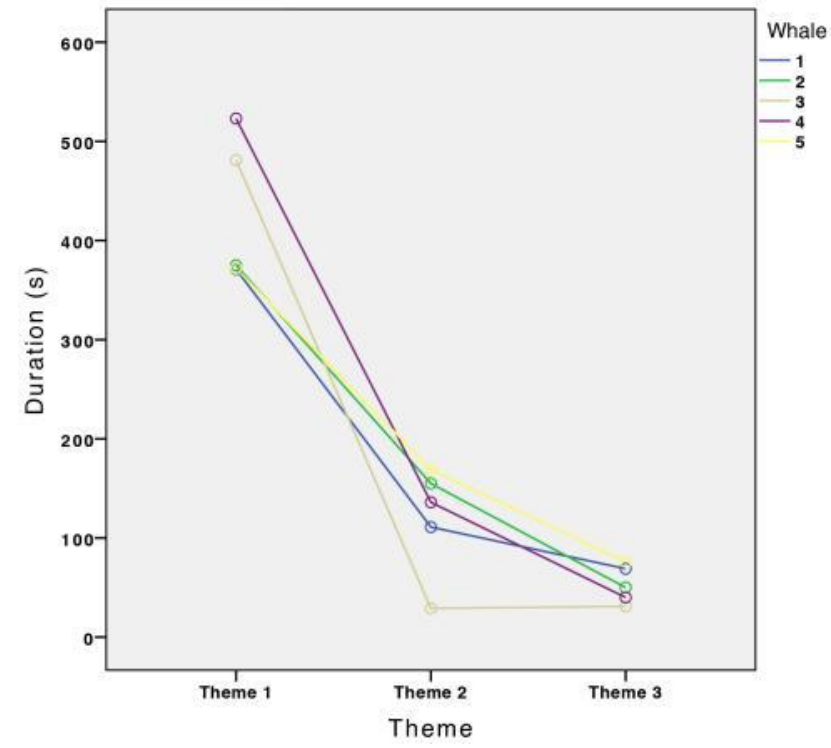

Figure 5. The average duration (in seconds) that each individual whale spent singing each theme. Each whale is denoted by a different color.

onds, and the longest was 12 minutes and 57 seconds. However, within an individual whale's song session, the duration of each song increased with successive renditions. In song sessions consisting of more than 3 songs, the duration of the last song recorded was always slightly shorter than the previous song. The number of songs in a song session ranged from less than $1 \mathrm{com}-$ plete song to 7 songs. However, recordings occasionally had to be stopped between songs due to limitations in the field (e.g., weather, fuel complications), which made comparisons regarding song session length from the current data set impossible.

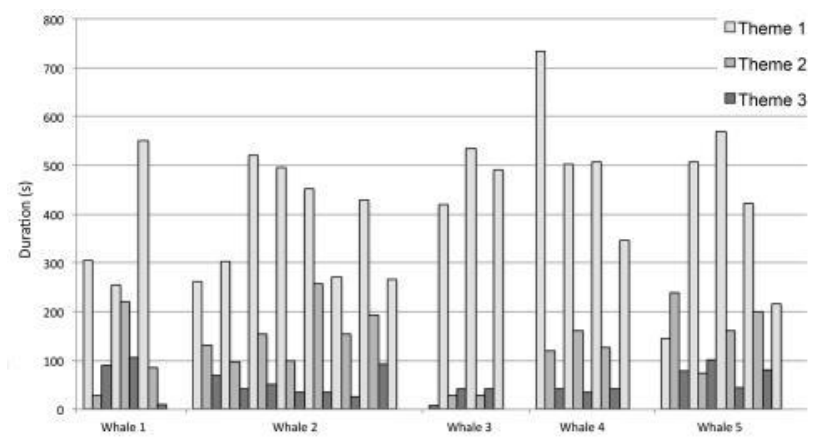

Figure 6. Distribution of themes across song sessions for each whale. Theme 1 (in light grey) is consistently the longest theme overall, and is generally the longest theme in each song session.

\section{DISCUSSION}

Research efforts on species preservation and habitat diversity in the Gulf of Tribugá remain limited, and significant information gaps persist in the study of the behavioral ecology of humpback whales in this area. Most importantly, the study of humpback whale song along the Pacific coast of Colombia is novel. In this report, the authors have put forth the first description of stock G's song in the Gulf of Tribugá during the breeding season of 2013. This paper illustrates that the song is highly organized (e.g., Winn and Winn 1978, Payne et al. 1983) and shared by individuals of the specific population (e.g., Winn and Winn 1978, Winn et al. 1981, Guinee et al. 1983, Payne and Payne 1985, Garland et al. 2015). It follows the same ordered and consistent theme repetition described in other populations (Payne and McVay 1971, Winn and Winn 1978, Payne et al. 1983, Payne and Payne 1985, Jenkins et al. 1995, Darling and Sousa-Lima 2005).

Initial duration analyses like the one detailed in this report are critical to the long-term understanding of song, as this parameter is a result of the hierarchical structure of song (Payne et al. 1983). Furthermore, Payne et al. (1983) suggested that differences in song duration might be due to the omission of certain themes within a song. However, the current study provides documentation that the five whales recorded never omitted a theme. The range of song duration reported here falls within the normal durations reported in early studies (Payne and McVay 1971, Payne and Payne 1985). Song duration can also be affected by the duration and number of phrase repetitions, which influence the length of each theme (Payne et al. 1983). Accordingly, duration was variable across themes in the current study, as has been reported in other populations (Payne et al. 1983, Darling and Sousa-Lima 2005, Darling et al. 2014,). Theme 1 was the dominant, or most frequently sung, theme in the 2013 recordings, consistent with previous descriptions of certain themes or phrases as consistently more frequent in production than others (Mercado et al. 2003, Darling and Sousa-Lima 2005, Murray et al. 2012).

Duration of phrases, and therefore themes, may eventually change over time. In 2013, theme 1 was the longest in duration, potentially due to the simplicity of unit types that constituted each phrase. For example, one phrase of theme 3 consisted of 5 different units, while in theme 1 there were only 3 units used within a phrase. Payne et al. (1983) suggest that the evolution of duration in phrases, and therefore themes, is something that needs to be analyzed over a multi-season comparison, which is beyond the limits of the current study. Subsequent analyses will determine if the same phrases continue to account for the greatest proportion 
of the song across years, as was the case for two phrase types in a study conducted in Hawaii (Mercado et al. 2003). The current initial description will allow for these necessary multi-year comparisons for stock $\mathrm{G}$.

Transitional phrases in Colombian song are composed of a combination of units present in the previous and subsequent themes, thus acting as a transition between the two (Payne et al. 1983). Although Payne and colleagues (1983) stated that transitional phrases may vary in their complexity, both transitional phrases transcribed in the current analysis were fairly simple in that they did not vary in complexity across individuals or within song sessions. However, their structure will likely change in subsequent years as the stability of the song changes (Payne et al. 1983). Phrases 1-2 and 3-1 were used consistently throughout each song session, which is consistent with what has been cited as transitional in other studies (e.g., Murray et al. 2012). Interestingly, a transitional phrase was never noted between themes 2 and 3. This consistent absence of a transition between specific themes has also been noted elsewhere in the literature (Cholewiak et al. 2013). The presence or absence of transitions may also be related to the stability of the song (Payne et al. 1983), and may indicate that song during the 2013-breeding season in Colombia was undergoing structural changes. Further work studying consecutive breeding seasons in Colombia will address the consistency and complexity of these transitional phrases.

The hierarchical structure of the song of stock $G$ was composed of units, which were grouped together into distinct phrases, which were repeated to form a theme. Three different themes were transcribed from 2013 data. The vagueness of phrase, and therefore subphrase, structure across the literature has been discussed in terms of comparability of song descriptions (Cholewiak et al. 2013). The authors chose to delineate subphrases within each phrase to describe the song of stock $G$ in detail to aide future geographic and longitudinal comparisons (Winn and Winn 1978, Payne et al. 1983, Cholewiak et al. 2013 (motifs)). Two subphrases were noted within each theme, consistent with early descriptions from Hawaii (Payne et al. 1983). The strong similarities in hierarchical structure of stock G's song to the song of multiple stocks on other breeding grounds provide the foundation for further comparative analyses.

Many studies within the song literature compare the song of different populations (Cerchio et al. 2001, Darling and Sousa-Lima 2005, Murray et al. 2012, Garland et al. 2011, 2015). Future studies should seek to expand the current report on Colombia's stock $G$ song via collaborative global comparisons with whale stocks in other locations. These collaborative efforts will help the scientific community to better understand the underlying mechanism of cultural transmission of song across ocean basins (Garland et al. 2011).

While the data presented here come from a single breeding season and five individual whales, the re-sighting history and physical description of the study site provided in the methods suggest that each song session analyzed was from a distinct individual, which is critical to the analysis of song structure (Cerchio et al. 2001, Murray et al. 2012). Continued longitudinal analyses will elucidate the changing nature of the song, which may have been limited during the 2013 season of data collection by occasional weather or fuel-related interruptions to recordings. Weather is an unavoidable and unpredictable issue within the Colombian
Pacific, but continuing grants in future years will alleviate fuel limitations.

LOCAL CONSERVATION IMPLICATIONS. Song is heard extensively in breeding areas, and this migratory species faces a complex set of environmental and anthropogenic pressures within limited breeding areas. Fishing and whale watching ecotourism are major sources of livelihood for the local communities in the Gulf of Tribugá. While local residents and visitors see humpback whales frequently, many have never heard humpback whale song. Since the initiation of this study in 2013 , song recordings have been used as a tool to educate the communities about the importance of conservation and to increase awareness of the whales' presence in the Gulf. Groups of students and environmental guides from the local communities were invited on boat trips to hear the whales in situ and learn about the research process. continued efforts to educate the community and ecotourism industry will endeavor to promote behavioral changes that improve the safety of the public's interactions with humpback whales during their breeding season.

\section{CONCLUSION}

The data presented in this study provide an important initial description of song structure in the Gulf of Tribugá, and are part of an ongoing study to characterize the shared song type of stock $G$ used during a given season and across consecutive years. Understanding the song of a single stock over time will allow for specific descriptions of individual changes over time, as photo-identification records are matched to known singers. Correspondingly, the long-term results of this ongoing work will contribute to our understanding of song. Future work to acoustically assess the relationship of Colombian song to song on other breeding grounds will add to the ongoing discussion of the similarities in song within an ocean basin and the dissimilarities across discrete locations.

\section{ACKNOWLEDGEMENTS}

Our greatest gratitude is extended to the local communities in The Gulf of Tribugá. We are very grateful to Dr. Jim Darling for assistance with methodology and the structure needed to transcribe the data early on, to Dr. Eduardo Mercado III for invaluable feedback and input on the analysis and interpretation, and Dr. Ellen Garland for help with statistical questions and input on future endeavors. We would also like to acknowledge the valuable input we received from three anonymous reviewers. Cetacean Society International, Idea Wild, Rufford Small Grants for Nature Conservancy, the Society for Marine Mammology, and indiegogo.com provided grants and funding for this project. We would like to thank Andrés Cañas, Maria Camila Medina, Andrea Caicedo González, Nadya Ramírez, and Alejandra Neira for assisting with data collection, and Luz Helena Rodriguez for assisting with grant applications. Finally, the authors would like to dedicate this publication in memory of the late Dr. Stan A. Kuczaj II.

\section{REFERENCES}

Au, W. W. L. and Hastings, M. C. 2008. Principles of Marine Bioacoustics. Springer, New York.

Au, W. W. L., Pack, A. A., Lammers, M. O., Herman, L. M., Deakos, M. H., and Andrews, K. 2006. Acoustic properties of humpback whale song. Journal of the Acoustical Society of America 120, 2: 1103-1110. (doi:10.1121/1.2211547) 
Cantera, J. 1993. Oceanografía. In: Colombia Pacífico Tomo I. P. Leyva (ed.), pp 12-23. Fondo para la Protección del Medio Ambiente "José Celestino Mutis" FEN Colombia, Bogotá, Colombia.

Cerchio, S., Jacobsen, J. K. and Norris, T. F. 2001. Temporal and geographical variation in songs of humpback whales, Megaptera novaeangliae: synchronous change in Hawaiian and Mexican breeding assemblages. Animal Behaviour 62, 2: 313-329. (doi:10.1006/anbe.2001.1747)

Cholewiak, D. M., Sousa-Lima, R. S. and Cerchio, S. 2013. Humpback whale song hierarchal structure: Historical context and discussion of current classification issues. Marine Mammal Science 29, 3: E312-E332. (doi:10.1111/mms.12005)

Clapham, P. J. and Mead, J. J. 1999. Megaptera novaeangliae. Mammalian Species 604. 1-9. (doi:10.2307/3504352)

Clark, C. W. and Clapham, P. J. 2004. Acoustic monitoring on a humpback whale (Megaptera novaeangliae) feeding ground shows continual singing into late spring. Proceedings of the Royal Society of London B 271, 1543: 1051-1057. (doi:10.1098/rspb.2004.2699)

Darling, J. D. 2001. Characterization of behavior of humpback whales in Hawaiian waters. Retrieved from the Hawaiian Islands Humpback Whale National Marine Sanctuary, Division of Aquatic Resources, Department of Land and Natural Resources. (available as Supplementary Material)

Darling, J. D. and Sousa-Lima, R. S. 2005. Songs indicate interaction between humpback whale (Megaptera novaeangliae) populations in the western and eastern south Atlantic Ocean. Marine Mammal Science 21, 3: 557-566. (doi:10.1111/j.1748-7692.2005.tb01249.x)

Darling, J. D., Acebes, J. M. V. and Yamaguchi, M. 2014. Similarity yet a range of differences between humpback whale songs recorded in the Philippines, Japan and Hawaii in 2006. Aquatic Biology 21, 2: 93-107. (doi:10.3354/ab00570)

Díaz, G. 1998. Derrotero del Pacífico Colombiano. Acta Oceanográfica Del Pacífico 9, 1: 199-208.

Díaz, J. M. 2002. Golfos y Bahías de Colombia. www.imeditores.com/banocc/golfos Downloaded 21 March 2016.

Eriksen, N., Miller, L. A., Tougaard, J. and Helweg, D. A. 2005. Cultural change in the songs of Humpback whales (Megaptera novaeangliae) from Tonga. Behaviour 142, 3: 305-328. (doi:10.1163/1568539053778283)

Eslava, J. A. 1993. Climatología. In: Colombia Pacífico Tomo I P. Leyva (ed.), pp. 138-147. Fondo para la Protección del Medio Ambiente "José Celestino Mutis" FEN Colombia, Bogotá, Colombia.

Galvis, J. and Mojica, J. 1993. Geología. In: Colombia Pacífico Tomo I. P. Leyva (ed.), pp. 80-95. Fondo para la Protección del Medio Ambiente "José Celestino Mutis" FEN Colombia, Bogotá, Colombia.

Garland, E. C., Goldizen, A. W., Rekdahl, M. L., Constantine, R., Garrigue, C., et al. 2011. Dynamic horizontal cultural transmission of humpback whale song at the ocean basin scale. Current Biology 21, 8: 687-691. (doi:10.1016/j.cub.2011.03.019)

Garland, E. C., Gedamke, J., Rekdahl, M. L., Noad, M. J., Garrigue, C. and Gales, N. 2013. Humpback whale song on the Southern Ocean feeding grounds: implications for cultural transmission. PLOS ONE 8, 11: e79422. (doi:10.1371/journal.pone.0079422)

Garland, E. C., Goldizen, A. W., Lilley, M. S., Rekdahl, M. L., Garrigue, C., et al. 2015 Population structure of humpback whales in the western and central South Pacific Ocean as determined by vocal exchange among populations. Conservation Biology 29, 4: 1198-1207. (doi:10.1111/cobi.12492)

Guinee, L. N., Chu, K. and Dorsey, E. M. 1983. Changes over time in the songs of known individual humpback whales (Megaptera novaeangliae). In: Communication and Behavior of Whales. R. Payne (ed.), pp 59-80. Westview Press, Boulder, CO.

Jaramillo, C. and Bayona, G. 2000. Mangrove distribution during the Holocene in Tribugá Gulf, Colombia. Biotropica 32,1: 14-22. (doi:10.1646/00063606(2000)032[0014:MDDTHI]2.0.CO;2)

Jenkins, P. F., Helweg, D. A. and Cato, D. H. 1995. Humpback whale song in Tonga: initial findings. In: Sensory Systems of Aquatic Mammals. R. A. Kastelein, J. A. Thomas and P. E. Nachtigall (eds.), pp 335-345. De Spil Publishers, Woerden, The Netherlands.
Mercado III, E., Herman, L. M. and Pack, A. A. 2003. Stereotypical sound patterns in humpback whale songs: Usage and function. Aquatic Mammals 29, 1: 37-52. (doi:10.1578/016754203101024068)

Murray, A., Cerchio, S., McCauley, R., Jenner, C. S., Razafindrakoto, Y., Coughran, D. McKay, S. and Rosenbaum, H. 2012. Minimal similarity in songs suggests limited exchange between humpback whales (Megaptera novaeangliae) in the southern Indian Ocean. Marine Mammal Science 28, 1: E41-E57. (doi:10.1111/j.1748-7692.2011.00484.x)

Noad, M. J., Cato, D. H., Bryden, M. M., Jenner, M. N. and Jenner, K. C. S. 2000. Cultural revolution in whale songs. Nature 408: 537. (doi:10.1038/35046199)

Norris, T. F., McDonald, M. and Barlow, J. 1999. Acoustic detections of singing humpback whales (Megaptera novaeangliae) in the eastern North Pacific during their northbound migration. Journal of the Acoustical Society of America 106, 1: 506-514.

Oviedo, L., Guzman, H. M., Flórez-González, L., Alzueta, J. C. and Mair, J. M. 2008 The song of the Southeast Pacific humpback whale (Megaptera novaeangliae) off Las Perlas Archipelago, Panama: Preliminary characterization. Aquatic Mammals 34, 4: 458-463. (doi:10.1578/AM.34.4.2008.458)

Payne, R. and McVay, S. 1971. Songs of humpback whales. Science 173: 585-597. (doi:10.1126/science.173.3997.585)

Payne, K. and Payne, R. 1985. Large scale changes over 19 years in songs of humpback whales in Bermuda. Zeitschrift für Tierpsychologie 68, 2: 89-114. (doi:10.1111/j.1439-0310.1985.tb00118.x)

Payne, K., Tyack, P. and Payne, R. 1983. Progressive changes in the songs of humpback whales (Megaptera novaeangliae): A detailed analysis of two seasons in Hawaii. In: Communication and Behavior of Whales. R. Payne (ed.), pp 9-57. Westview Press, Colorado.

Stimpert, A. K., Peavey, L. E., Friedlaender, A. S. and Nowacek, D. P. 2012. Humpback whale song and foraging behavior on an antarctic feeding ground. PLOS ONE 7, 12: e51214. (doi:10.1371/journal.pone.0051214)

Winn, H. E. and Winn, L. K. 1978. The song of the humpback whale Megaptera novaeangliae in the West Indies. Marine Biology 47, 2: 97-114. (doi:10.1007/BF00395631)

Winn, H. E., Thompson, T. J., Cummings, W. C., Hain, J., Hudnall, J., Hays, H. and Steiner, W. W. 1981. Songs of the humpback whale - population comparisons. Behavioral Ecology and Sociobiology 8, 1: 41-46. (doi:10.1007/BF00302842)

\section{SUPPLEMENTARY MATERIAL}

Available online only

Table S1. Auditory descriptions, duration (seconds), and frequency (hertz) parameters of individual units analyzed from the Colombia 2013 songs.

Table S2. Additional information from data collection protocol and environmental parameters (when available) to compliment methodology.

Figure S1. A. The relative theme representations for the Colombia 2013 songs. The dominant theme (theme 1) was sung for $>70 \%$ of the song, and the minor themes (themes 2 and 3) were sung for $20 \%$ of the song or less. B. The proportion of total theme renditions (64) throughout the Colombia 2013 songs. Themes 1, 2, and 3 had 25,19 , and 20 renditions respectively.

Darling, J. D. 2001. Characterization of behavior of humpback whales in Hawaiian waters. Retrieved from the Hawaiian Islands Humpback Whale National Marine Sanctuary, Division of Aquatic Resources, Department of Land and Natural Resources. 
Perazio, C. E., Zapetis, M. E., Roberson, D., Botero, N. and Kuczaj II, S. 2017. Humpback whale, Megaptera novaeangliae, song during the breeding season in the Gulf of Tribugá, Colombian Pacific. Madagascar Conservation \& Development 13,1: 83-90. http://dx.doi.org.104314/mcd.whales.1

Supplementary Material

\section{SUPPLEMENTARY MATERIAL}

Table S1. Equations for the estimation of each dendrometric factor ( ${ }^{*}$ in $\mathrm{Hz}$ )

\begin{tabular}{|c|c|c|c|c|c|c|c|c|c|c|c|}
\hline \multirow{3}{*}{$\begin{array}{l}\text { Unit } \\
A_{1}\end{array}$} & \multirow{3}{*}{\begin{tabular}{|l}
$\begin{array}{l}\text { Auditory } \\
\text { description }\end{array}$ \\
$\begin{array}{l}\text { flat, wideband, with a } \\
\text { greater frequency } \\
\text { range than } \mathrm{A}_{2}\end{array}$ \\
\end{tabular}} & \multicolumn{3}{|c|}{ Duration (s) } & \multicolumn{2}{|c|}{ Average Frequency ${ }^{*}$} & \multirow{2}{*}{\multicolumn{2}{|c|}{$\begin{array}{l}\text { Frequency } \\
\text { range }\end{array}$}} & \multicolumn{3}{|c|}{ Fundamental Frequency* } \\
\hline & & \multirow{2}{*}{\begin{tabular}{|c|} 
Average \\
1.7
\end{tabular}} & \multicolumn{2}{|c|}{ Range } & \multirow{2}{*}{$\begin{array}{l}\text { High } \\
4103\end{array}$} & \multirow{2}{*}{$\begin{array}{l}\text { Low } \\
102\end{array}$} & & & \multirow{2}{*}{$\begin{array}{c}\text { Average } \\
330.3\end{array}$} & \multicolumn{2}{|c|}{ Range } \\
\hline & & & 0.4 & 3.3 & & & 0 & 16337.6 & & 23.4 & 1921.9 \\
\hline $\mathrm{A}_{2}$ & $\begin{array}{l}\text { flat, wideband, with a } \\
\text { higher average } \\
\text { fundamental } \\
\text { frequency }\end{array}$ & 1.5 & 0.4 & 2.8 & 3479.9 & 117.4 & 56.2 & 9571.8 & 396.6 & 117.2 & 937.5 \\
\hline B & $\begin{array}{l}\text { flat, wideband, with a } \\
\text { larger frequency } \\
\text { range than } A_{1} \text { or } A_{2}\end{array}$ & 1.4 & 0.5 & 2.7 & 4319.1 & 207.5 & 9.9 & 14377.6 & 341.2 & 46.9 & 984.4 \\
\hline $\mathrm{Bl}_{1}$ & $\begin{array}{l}\text { clear harmonics, } \\
\text { quick upsweep }\end{array}$ & 0.5 & 0.4 & 1 & 2764.6 & 173.4 & 14.3 & 5262.8 & 393.7 & 75 & 1289.1 \\
\hline $\mathrm{Bl}_{2}$ & $\begin{array}{l}\text { no clear harmonics, } \\
\text { quick upsweep }\end{array}$ & 0.7 & 0.3 & 1.1 & 2872.7 & 189.9 & 48.9 & 6878.2 & 486.6 & 117.2 & 1101.6 \\
\hline $\mathrm{F}$ & low groan & 0.7 & 0.1 & 1.6 & 1782.3 & 90.9 & 20.2 & 4240 & 309.9 & 70.3 & 1171.9 \\
\hline LU & long, tonal upsweep & 3.3 & 1.8 & 4.3 & 8169.6 & 576.7 & 224.1 & 15388.2 & 877.9 & 656.2 & 3328.1 \\
\hline SU & short, tonal upsweep & 1.2 & 0.7 & 1.5 & 8212.8 & 557.7 & 435.1 & 15782.2 & 715.8 & 515.6 & 1418 \\
\hline LD & $\begin{array}{l}\text { long, tonal } \\
\text { downsweep }\end{array}$ & 2.6 & 2 & 3.2 & 9084.2 & 902.1 & 830.7 & 17959.5 & 1887.8 & 949.2 & 3726.6 \\
\hline SD & $\begin{array}{l}\text { short, tonal } \\
\text { downsweep }\end{array}$ & 1 & 0.5 & 1.4 & 10359.9 & 966.8 & 751.6 & 19027.6 & 2687.9 & 1148.4 & 6398.4 \\
\hline$S$ & squeak & 0.3 & 0.2 & 0.4 & 15776.3 & 1922.7 & 1068.1 & 18157.3 & 2802.4 & 1195.3 & 5250 \\
\hline
\end{tabular}


Perazio, C. E., Zapetis, M. E., Roberson, D., Botero, N. and Kuczaj II, S. 2017. Humpback whale, Megaptera novaeangliae, song during the breeding season in the Gulf of Tribugá, Colombian Pacific. Madagascar Conservation \& Development 13,1: 83-90. http://dx.doi.org.104314/mcd.whales.1

Supplementary Material

Table S2. Additional information from data collection protocol and environmental parameters (when available) to compliment methodology.

\begin{tabular}{|c|c|c|c|c|c|}
\hline Date & 2 VIII 2013 & 9 VIII 2013 & 8 XII 2013 & 9 IX 2013 & 13 IX 2013 \\
\hline GPS points & $\begin{array}{l}\text { W077 } 25^{\prime} 28.7^{\prime \prime} \\
\text { N05 } 41^{\prime} 18.6^{\prime \prime}\end{array}$ & $\begin{array}{l}\text { W077 } 25^{\circ} 28.7^{\prime \prime} \\
\text { N } 05^{\circ} 41^{\prime} 18.6^{\prime \prime}\end{array}$ & 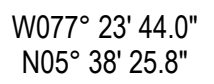 & $\begin{array}{l}\text { W077 } 24^{\prime} 46.0^{\prime \prime} \\
\text { N05 } 38^{\prime} 11.2^{\prime \prime}\end{array}$ & $\begin{array}{l}\text { W077 } 37^{\circ} \text { '0.5" } \\
\text { N05 } 34^{\circ} 40.1^{\prime \prime}\end{array}$ \\
\hline Photos & NO & NO & YES & NO & YES \\
\hline Recording length & $00: 34: 41$ & 01:43:03 & 00:39:01 & $00: 50: 00$ & 00:58:06 \\
\hline Wildlife & None & None & None & None & None \\
\hline $\mathrm{Ph}$ & NA & NA & 8.5 & NA & 7.7 \\
\hline Salinity & NA & NA & 26.0ppt & NA & 23.3ppt \\
\hline Air temperature & NA & NA & $31.4^{\circ} \mathrm{C}$ & NA & $30.0^{\circ} \mathrm{C}$ \\
\hline Water temperature & NA & NA & $27.6^{\circ} \mathrm{C}$ & NA & $28.6^{\circ} \mathrm{C}$ \\
\hline Wind speed & NA & NA & $0.2 \mathrm{~m} / \mathrm{s}$ & NA & $4.3 \mathrm{~m} / \mathrm{s}$ \\
\hline Dissolved oxygen & NA & NA & $5.87 \mathrm{mg} / \mathrm{L}$ & NA & $5.89 \mathrm{mg} / \mathrm{L}$ \\
\hline
\end{tabular}
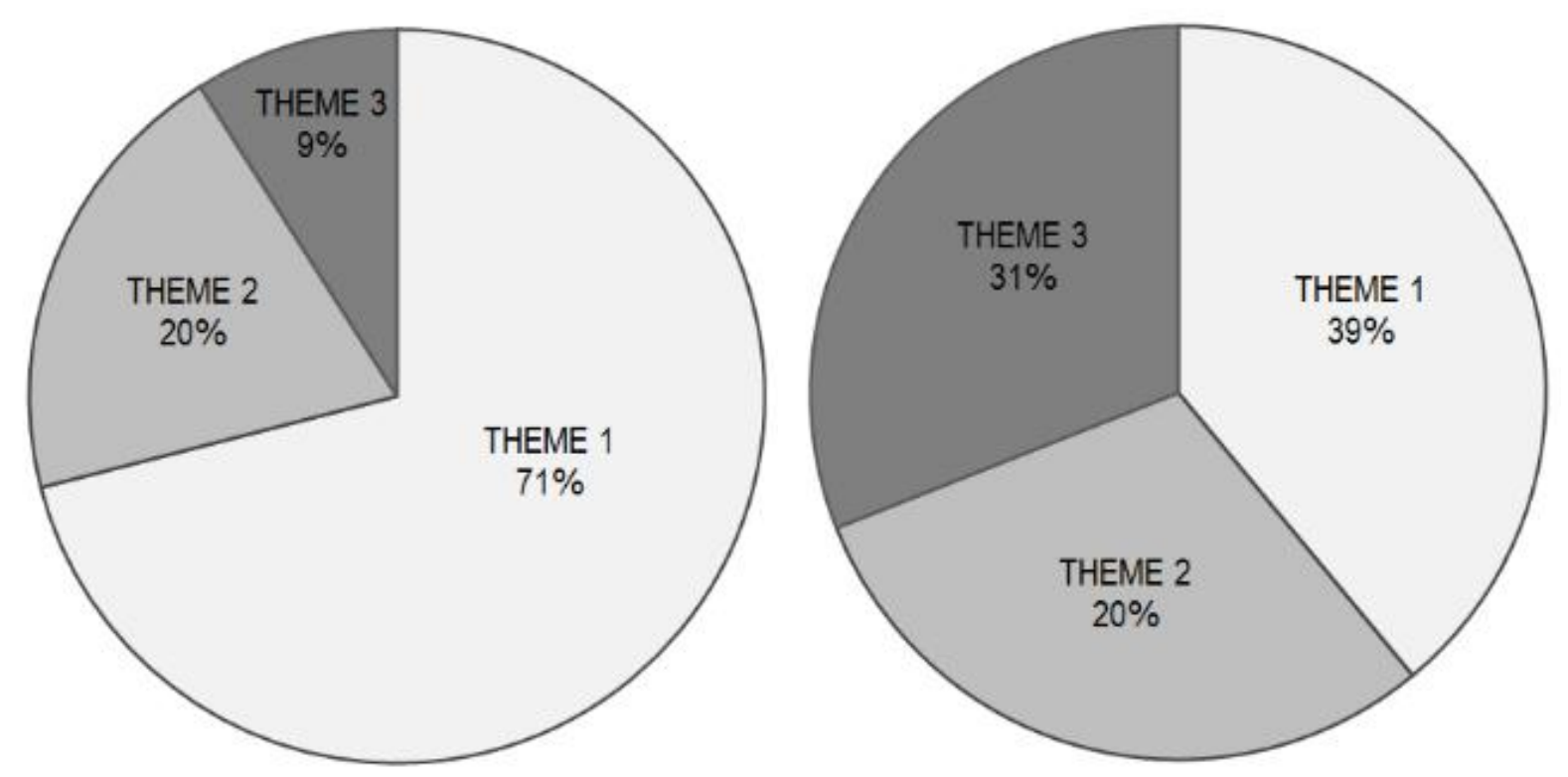

Figure S1. A. The relative theme representations for the Colombia 2013 songs. The dominant theme (theme 1) was sung for $>70 \%$ of the song, and the minor themes (themes 2 and 3 ) were sung for $20 \%$ of the song or less. B. The proportion of total theme renditions (64) throughout the Colombia 2013 songs. Themes 1, 2, and 3 had 25,19 , and 20 renditions respectively. 